Article

\title{
Energy Recovery from Sewage Sludge: The Case Study of Croatia
}

\author{
Dinko Đurđević $^{1, *(0)}$, Paolo Blecich ${ }^{2} \mathbb{1}$ and Željko Jurić ${ }^{1}$ \\ 1 Energy Institute Hrvoje Požar, 10000 Zagreb, Croatia; zjuric@eihp.hr \\ 2 Faculty of Engineering, University of Rijeka, 51000 Rijeka, Croatia; paolo.blecich@riteh.hr \\ * Correspondence: ddurdevic@eihp.hr
}

Received: 26 April 2019; Accepted: 16 May 2019; Published: 20 May 2019

\begin{abstract}
Croatia produced 21,366 tonnes of dry matter (DM) sewage sludge (SS) in 2016, a quantity expected to surpass 100,000 tonnes DM by 2024. Annual production rates for future wastewater treatment plants (WWTP) in Croatia are estimated at 5.8-7.3 $\mathrm{Nm}^{3} /$ people equivalent (PE) for biogas and $20-25 \mathrm{~kg} g_{\mathrm{DM}} / \mathrm{PE}$ of sewage sludge. Biogas can be converted into $12-16 \mathrm{kWh} / \mathrm{e} / \mathrm{PE}$ of electricity and $19-24 \mathrm{kWh}_{\mathrm{th}} / \mathrm{PE}$ of heat, which is sufficient for $30-40 \%$ of electrical and $80-100 \%$ of thermal autonomy. The WWTP autonomy can be increased using energy recovery from sewage sludge incineration by $60 \%$ for electricity and $100 \%$ of thermal energy $(10-13 \mathrm{kWh} / \mathrm{PE}$ and $30-38 \mathrm{kWh}$ th $/ \mathrm{PE})$. However, energy for sewage sludge drying exceeds energy recovery, unless solar drying is performed. The annual solar drying potential is estimated between $450-750 \mathrm{~kg} \mathrm{DM} / \mathrm{m}^{2}$ of solar drying surface. The lower heating value of dried sewage sludge is $2-3 \mathrm{kWh} / \mathrm{kg}_{\mathrm{DM}}$ and this energy can be used for assisting sludge drying or for energy generation and supply to WWTPs. Sewage sludge can be considered a renewable energy source and its incineration generates substantially lower greenhouse gases emissions than energy generation from fossil fuels. For the same amount of energy, sewage sludge emits $58 \%$ fewer emissions than natural gas and $80 \%$ less than hard coal and fuel oil. Moreover, this paper analysed the feasibility of sludge disposal practices by analysing three scenarios (landfilling, co-incineration, and mono-incineration). The analysis revealed that the most cost-effective sewage sludge disposal method is landfilling for $60 \%$ and co-incineration for $40 \%$ of the observed WWTPs in Croatia. The lowest $\mathrm{CO}_{2}$ emissions are obtained with landfilling and mono-incineration in $53 \%$ and $38 \%$ of the cases, respectively.
\end{abstract}

Keywords: wastewater treatment; sewage sludge; solar drying; energy recovery; incineration

\section{Introduction}

Sewage sludge is a by-product of wastewater treatment plants (WWTP), considered valuable for its content of nutrients and energy but also a potential threat to humans and the environment because of the presence of organic pollutants and heavy metals. Sustainable solutions and the best available techniques for the treatment and disposal of sewage sludge, including recovery of energy and nutrients, are currently being discussed in the European Union (EU) [1]. The situation is particularly urgent in large and densely populated cities, which are producing large quantities of sewage sludge and have limited available surface area for its processing and disposal. The amount of sewage sludge produced in the EU per year was 10 million tonnes in 2008, 11.5 million tonnes in 2015 [2] and is expected to approach 13 million tonnes of dry matter (DM) by 2020 [3]. The quantity of sewage sludge generated in WWTPs is increasing with the progressive expansion of wastewater networks, but also due to population growth and industrial development. After adopting the Directive concerning Urban Wastewater Treatment 91/271/EEC, EU member states agreed to implement primary, secondary, and 
tertiary wastewater treatment processes (Figure 1), starting from large agglomerations and subsequently moving onto smaller ones.

Unlike wastewater treatment, at present there is no official regulation framework for the general management and disposal of sewage sludge in the EU. Sewage sludge management solutions need to be assessed taking into account environmental, economic, legislative, technical, and location criteria $[4,5]$. Different strategies for the treatment and final disposal are possible but the general opinion is that sewage sludge is a valuable source of energy and materials. There are two main pathways of sewage sludge management [6]: (1) organic recycling (use in agriculture, composting and land reclamation), and (2) recovery of energy and nutrients (mono- and co-incineration, pyrolysis, gasification, phosphorus, and nitrogen recovery).

Sewage sludge treatment includes various biological, chemical, and thermal processes, as well as long-term storage, which aim to remove pathogens and reduce sludge volume. Previous research focused on discovering the negative effects of pollutants in wastewater. Yoshida et al. [7] assessed the fate of 32 organic elements and four groups of organic pollutants in a conventional WWTP and concluded that both inorganic and organic elements are accumulated in sewage sludge, which presents a threat to the environment. Hadi et al. [8] investigated the adsorption mechanisms of pollutants in wastewater. Zhang et al. [9] examined the effect of filtration method as an alternative method to treat alfalfa wastewater, which proved to be very effective. Mo et al. [10] studied the adsorption effect of pollutants from agro-industrial waste to wastewater. The negative effects of these harmful elements can be reduced by different methods. The typical sewage sludge treatment process includes dewatering, thickening, stabilization (aerobic or anaerobic digestion), hygienisation, storage, drying, and transport. On the other hand, final disposal of the sewage sludge produced in the EU includes agricultural use $(42.4 \%)$, incineration (26.9\%), landfilling (13.6\%) and others (17.1\%-composting, long-term storage, and land reclamation) [2].

The average costs of wastewater treatment and recycling of raw sludge in agriculture are estimated at between 100 and $200 € / t_{\mathrm{DM}}$. The costs are between 200 and $400 € / \mathrm{t}_{\mathrm{DM}}$ in case of dewatered and dried sewage sludge for landfills, land reclamation and incineration $[2,6]$. The application of sewage sludge to agricultural lands is regulated by the Sewage Sludge Directive 86/278/EEC. The Directive defines the quantities, properties, composition, sampling, and testing of sewage sludge, as well as the maximum concentrations of pollutants and heavy metals [11,12].

In the past 20 years in the EU, sewage sludge treatment has relied on three main processes: dewatering and drying, stabilisation by anaerobic digestion and thermal treatment [13,14]. Anaerobic digestion (AD) is the preferred stabilisation method as it produces biogas, a valuable energy source [15]. In 2016, the EU produced 16.1 Mtoe (Million of tonnes of oil equivalent) of biogas, with sewage sludge feedstock contributing with 1.4 Mtoe of biogas (8.7\%) [16]. Biogas from sewage sludge generated $5400 \mathrm{GWh}$ of electricity and $650 \mathrm{GWh}$ of heat delivered into district heating networks [17]. Beside local use and electricity generation, biogas can be upgraded to biomethane for injection into natural gas networks or as transport fuel [16]. The digested sewage sludge has a recoverable energy potential, although lower than that of raw sewage sludge. Sewage sludge is dried and converted into energy in cogeneration plants, thermal power plants, waste-to-energy plants, cement kilns and mono-incineration plants $[4,18-20]$.

Recently, pyrolysis and gasification have proven to be environmentally safe and economically feasible solutions for sewage sludge treatment. Pyrolysis converts different types of sewage sludge (raw, digested and waste-activated) into usable oil and gas (syngas), forming a stabilized residue (biochar) as a by-product. AD followed by sludge pyrolysis yields higher rates of energy recovery than stand-alone AD or pyrolysis [14,21]. Gasification of sewage sludge, on the other hand, yields syngas that can fuel gas burners, cogeneration (CHP) systems, gas turbines and internal combustion engines. The generated heat and electricity can partially meet the demands of WWTPs. Electricity generation from syngas has shown higher efficiency than electricity generation from biogas [22]. Gasification of 
sewage sludge and waste vegetable oil for generation of syngas, which fuels CHP systems, is also a profitable and clean solution [23].

Nutrient recovery from sludge dewatering streams and incineration sludge ashes are emerging as promising processes with multiple benefits [24]. The recovery of nutrients from dewatering streams reduces the formation of struvite scale in the equipment and the obtained nutrients are recycled as fertilizers into the agricultural sector. Nutrients' recovery specifically focuses on phosphorus, which is a limited resource. The achievable potential for phosphorus recovery from sewage sludge is estimated at 300,000 tonnes per year in the EU. At the moment, about $25 \%$ of the phosphorus is recycled through the application of sewage sludge to soil [25]. However, many of the above mentioned technologies are still in the experimental phase or are not yet feasible.

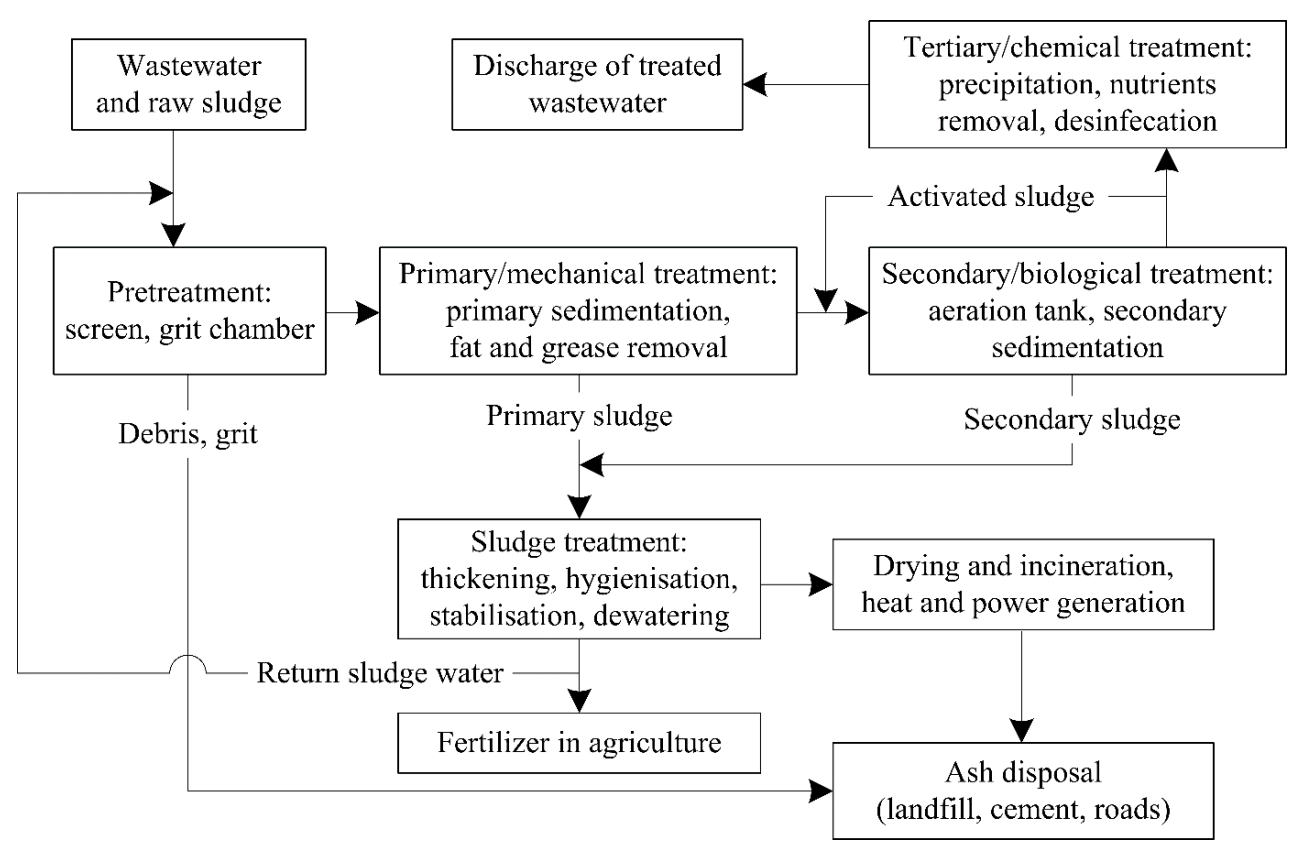

Figure 1. Main processes of wastewater and sewage sludge treatment in the EU.

The impact of the sewage sludge generated in Croatia is minor to the EU. In 2016, the amount of sewage sludge in Croatia was 21,366 tonnes dry matter, which represents less than $0.2 \%$ of the total sludge at the EU-28 level (11.5 million tonnes). Following the planned expansion and upgrade of the wastewater treatment system, the amount of sewage sludge could reach 100,000 tonnes by 2024 in Croatia, which would still be less than $1 \%$ of the amount generated at EU-28 level. Nevertheless, the EU-28 and Croatia are developing common sewage sludge management and final disposal strategies. In particular, anaerobic digestion for biogas generation, followed by incineration of dried stabilized sludge, and coupled to energy recovery solutions, are gaining much attention, lately.

This paper analyses the sludge management and disposal solutions applicable in Croatia. The biogas generation potential from anaerobic digestion and energy recovery from solar-dried and incinerated sewage sludge are discussed, as well as nutrient recovery and greenhouse gas (GHG) emissions from sludge treatment. The paper is organized as follows: Section 2 gives an overview on the wastewater loads and sewage sludge quantities in Croatia and compares Croatia with the sewage sludge management strategies in the EU while giving particular attention to mono-incineration with energy recovery as the emerging solution for final disposal. Section 3 analyses the energy generation potential of biogas and sewage sludge from the existing WWTP in Zagreb and planned major projects in Croatia. The energy balance between thermal drying and incineration of sewage sludge is studied showing the advantages of solar drying. In the end, disposal of incinerated sewage sludge ash and emissions of GHG are discussed. In Section 4, a discussion on the results was conducted, along with 
the analysis of three potential scenarios in Croatia for sewage sludge management options. Section 5 offers the conclusions of this paper.

\section{Sewage Sludge Management in Croatia}

\subsection{Sewage Sludge Disposal Practices}

Sewage sludge is considered a valuable resource because it contains two components that are economically and technically recoverable: energy and nutrients. Old (EU-15) and new EU member states (EU-13) have different strategies regarding sewage sludge management. At present, old member states produce $87.7 \%$ of the total quantity of sewage sludge in the EU. Incineration is the second most preferred disposal method in the EU-15 (29.5\%), after reuse in agriculture $(42.7 \%)$ and ahead of landfilling $(10.6 \%)$, and other methods (17.2\%). In the EU-13, incineration is less used (8.3\%) with respect to agricultural reuse (41\%), landfilling (34.8\%), and other methods $(15.9 \%)$ [2].

Sewage sludge is comparable to wood biomass in terms of energy content [26-28] but with higher inorganic (ash) content. The heating value of sewage sludge dry matter is $17-18 \mathrm{MJ} / \mathrm{kg}$ for raw sludge (RS), 14-16 MJ/kg for active sludge (AS) and 8-12 MJ/kg for stabilized sludge (SS) [21,29].

Sewage sludge thermal treatment methods include: mono-incineration and co-incineration, pyrolysis, gasification, wet oxidation, thermal hydrolysis, hydrothermal carbonization (HTC) and biofuel production by microorganisms. The available methods for thermal treatment of sewage sludge are listed in Table 1. Pyrolysis of sewage sludge consist of heating of sewage sludge to elevated temperatures, under anoxic conditions. This process removes the organic substance by thermal cleaning and produces bio-oil and biogas with heating values in the range of $30-37 \mathrm{MJ} / \mathrm{kg}$ and $15-20 \mathrm{MJ} / \mathrm{m}^{3}$, respectively [21]. Gasification converts the carbon content of sewage sludge into syngas by partial oxidation at elevated temperatures with a reducing atmosphere. The syngas is composed of $\mathrm{H}_{2}$, $\mathrm{CO}, \mathrm{CH}_{4}, \mathrm{CO}_{2}, \mathrm{~N}_{2}$ and $\mathrm{H}_{2} \mathrm{O}$ and achieves heating values in the range of $10-20 \mathrm{MJ} / \mathrm{m}^{3}$, depending on the type of oxidant [22]. Wet oxidation dissolves the organic content of sewage sludge into $\mathrm{H}_{2} \mathrm{O}$ and $\mathrm{CO}_{2}$, in water with oxygen or air as the oxidant, at temperatures between 200 and $300{ }^{\circ} \mathrm{C}$. Wet oxidation is an exothermic process, which can supply process heat. Hydrothermal carbonization is a hydrothermal process that converts the solid fraction of sewage sludge into a char-like product (HTC coal). The reaction is performed at temperatures of around $200{ }^{\circ} \mathrm{C}$ and pressures of about $20 \mathrm{bar}$. After drying, the HTC coal can be used as low-grade solid fuel with heating values of 10-15 MJ/kg [30].

Incineration of sewage sludge is becoming the fastest growing disposal practice in the EU, with an increase from $19 \%$ in 2005 to $26.9 \%$ in 2010 [2,4] and expected to reach $32 \%$ by 2020 [3]. Incineration is the main alternative to agricultural reuse, especially where suitable soils for recycling are not available or public disapproval is present. Incineration reduces the mass and volume of sewage sludge, safely destroys harmful pathogens and can be combined with energy recovery systems. Usually, incineration is performed on stabilized and dewatered sludge. Self-sustained combustion of sewage sludge is achieved with DM contents as low as $30 \%$. However, due to a high water content, dewatered sludge has no practical energy value. In thermal power plants and waste incineration plants, sludge needs drying and grinding before co-incineration with lignite, coal, or municipal waste. Dried sludge $(90 \% \mathrm{DM})$ achieves heating values between 8 and $12 \mathrm{MJ} / \mathrm{kg}$ [31] and is also suitable for mono-incineration and cement production. Generally, mono-incineration plants have higher investment costs (between 200 and $400 € / t_{\mathrm{DM}}$ ) than co-incineration plants (between 150 and $300 € / \mathrm{t}_{\mathrm{DM}}$ ) [2].

Sewage sludge incineration is a potential source of harmful substances such as dioxins, furans, and heavy metals which are present both in flue gases and in the residual ash. Incinerated sewage sludge ash (ISSA) needs to be disposed of accordingly because of the presence of heavy metals. Sewage sludge ash is disposed in landfills, used as fertilizer in agriculture (depending on heavy metal content), or raw material for concrete and asphalt production. The main drawback of sludge incineration is that it hinders phosphorus recovery. 
Phosphorus recovery from sewage sludge ash is limited only to ashes with high concentrations of phosphorus, like those produced in mono-incineration plants. Phosphorus recovery from diluted ash that is produced in co-incineration plants is not feasible at present. In cement plants, sewage sludge is a source of energy and raw material, but phosphorus remains incorporated in the cement.

Table 1. Comparison of thermal treatment methods for sewage sludge [18,30,32-34].

\begin{tabular}{|c|c|c|c|c|c|}
\hline Parameter & $\begin{array}{l}\text { Anaerobic } \\
\text { Digestion }\end{array}$ & Incineration & Pyrolysis & Gasification & $\begin{array}{l}\text { Hydrothermal } \\
\text { Carbonization }\end{array}$ \\
\hline Temperature & $15-60^{\circ} \mathrm{C}$ & $800-1000{ }^{\circ} \mathrm{C}$ & $300-900{ }^{\circ} \mathrm{C}$ & $700-1000{ }^{\circ} \mathrm{C}$ & $180-250^{\circ} \mathrm{C}$ \\
\hline Main products & $\begin{array}{l}\text { stabilized sludge } \\
\text { and biogas }\left(\mathrm{CH}_{4} \text {, }\right. \\
\left.\qquad \mathrm{CO}_{2}, \mathrm{H}_{2} \mathrm{O}\right)\end{array}$ & $\begin{array}{l}\text { ash and flue gases } \\
\left(\mathrm{CO}_{2}, \mathrm{H}_{2} \mathrm{O}, \mathrm{CO}\right. \\
\left.\mathrm{NO}_{\mathrm{x}}, \mathrm{SO}_{\mathrm{x}}, \mathrm{PM}\right)\end{array}$ & $\begin{array}{c}\text { bio-char, bio-oil } \\
\text { and biogas }\left(\mathrm{H}_{2},\right. \\
\left.\mathrm{CH}_{4}, \mathrm{CO}_{2}\right)\end{array}$ & $\begin{array}{l}\text { bio-char, tar } \\
\text { and syngas }\left(\mathrm{H}_{2},\right. \\
\left.\mathrm{CO}, \mathrm{CH}_{4}, \mathrm{CO}_{2}\right)\end{array}$ & HTC coal \\
\hline $\begin{array}{l}\text { Harmful } \\
\text { substances }\end{array}$ & $\begin{array}{l}\text { pathogens, heavy } \\
\text { metals }\end{array}$ & \multicolumn{3}{|c|}{$\begin{array}{l}\text { heavy metals: mainly in the solid fraction } \\
\text { and traces in the gas fraction }\end{array}$} & $\begin{array}{l}\text { benzenes, } \\
\text { phenols, furans, } \\
\text { aldehydes and } \\
\text { ketones. }\end{array}$ \\
\hline Heating value & $\begin{array}{c}\text { biogas: } \\
15-27 \mathrm{MJ} / \mathrm{m}^{3}\end{array}$ & $\begin{array}{l}\text { SS: } 8-12 \mathrm{MJ} / \mathrm{kg}_{\mathrm{DM}} \\
\text { AS: } 14-16 \mathrm{MJ} / \mathrm{kg}_{\mathrm{DM}} \\
\text { RS: } 17-18 \mathrm{MJ} / \mathrm{kg}_{\mathrm{DM}}\end{array}$ & $\begin{array}{c}\text { bio-oil: } \\
\text { 30-37 MJ/kg } \\
\text { biogas: } \\
\text { 15-20 MJ/m } \mathrm{m}^{3}\end{array}$ & $\begin{array}{c}\text { syngas: } \\
10-20 \mathrm{MJ} / \mathrm{m}^{3}\end{array}$ & $\begin{array}{l}\text { HTC coal: } \\
10-15 \mathrm{MJ} / \mathrm{kg}\end{array}$ \\
\hline
\end{tabular}

\subsection{The Public Wastewater System in Croatia}

The public water supply system in Croatia has a population coverage rate of $93 \%$, according to the latest published data. Out of 4.285 million inhabitants, the share of population connected to the national water supply system is $84 \%$, while a further $4 \%$ have access to local water supply systems. The remaining $12 \%$ of the population is using individual solutions for accessing clean drinkable water [35].

On the other hand, the public wastewater system is less developed. Only $55 \%$ of the population uses the public wastewater systems. Large differences are encountered between urban and rural areas. The coverage rate for the public wastewater system is an average $75 \%$ in cities with more than 150,000 people equivalent (PE) but only 5\% in small towns with less than 2000 PE. The total amount of collected wastewater was 378 million $\mathrm{m}^{3}$ in 2017: $47 \%$ was generated by households, $33 \%$ by the industry, and $20 \%$ was from rainfall. Out of the total quantity of treated wastewaters, $32 \%$ were treated in wastewater plants with preliminary or primary treatment, $60 \%$ in plants with secondary treatment and $8 \%$ in plants with tertiary treatment, as shown in Figure 2 [36].

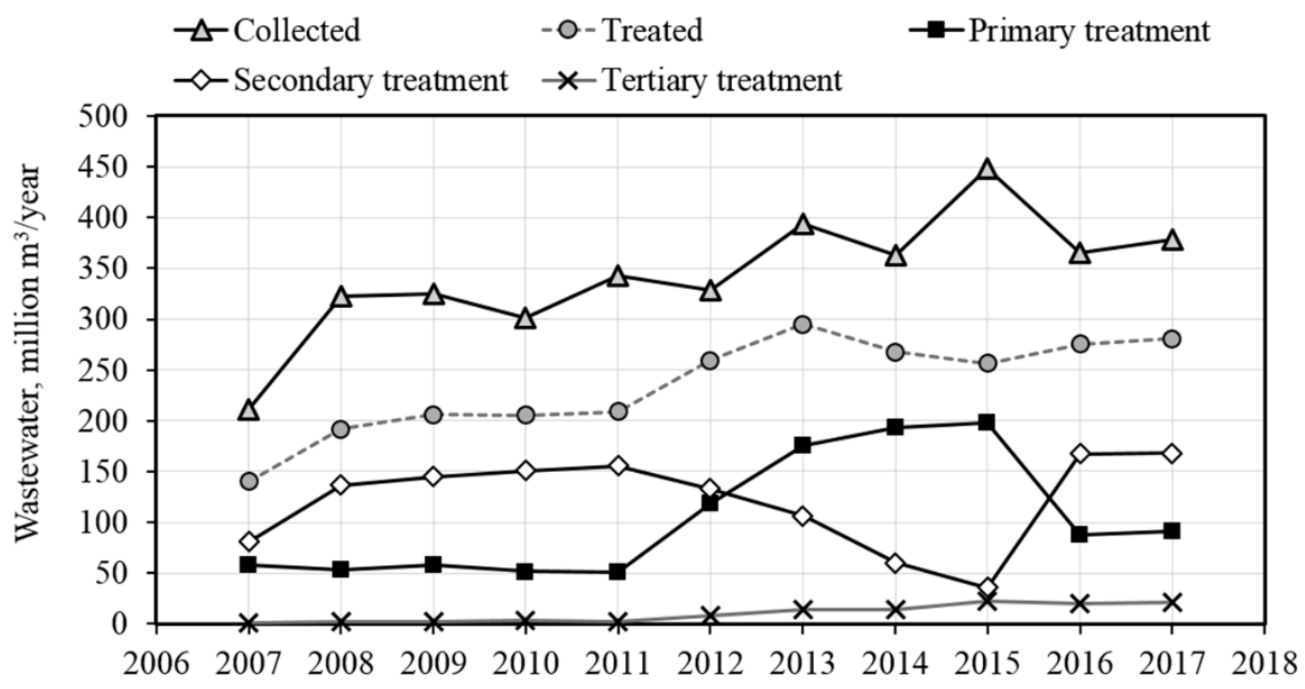

Figure 2. Collected and treated wastewaters in Croatia, 2007-2017. Data from [36]. 
At present in Croatia, wastewater and industrial wastewaters are treated in over 200 WWTPs with a total capacity of 4.1 million PE [35]. More than half of the wastewater and sewage sludge is produced in the four major agglomerations (Zagreb, Split, Rijeka, and Osijek), as shown in Figure 3.

The ongoing upgrades of the public wastewater system include all larger cities and industrial areas. In Croatia, 91 agglomerations have wastewater loads larger than 10,000 PE while another 190 agglomerations have wastewater loads in the range between 2000 and 10,000 PE. Following EU directives, secondary wastewater treatment is mandatory to agglomerations larger than 10,000 PE. Furthermore, agglomerations located within ecologically sensitive areas must implement tertiary wastewater treatment, including nitrogen and phosphorus removal. In Croatia, the ecologically sensitive areas are located in the drainage basins of Danube River and Adriatic Sea (Table 2) [37].

Table 2. Size and number of agglomerations in Croatia. Data from [37].

\begin{tabular}{cccc}
\hline \multirow{2}{*}{ Size of Agglomeration } & Number of Agglomerations & \multicolumn{2}{c}{ Drainage Basin } \\
\cline { 3 - 4 } & & Danube River & Adriatic Sea \\
\hline ES $\geq 150,000$ & 16 & 2 & 2 \\
$50,000 \leq \mathrm{ES}<150,000$ & 43 & 9 & 7 \\
$15,000 \leq \mathrm{ES}<50,000$ & 28 & 19 & 24 \\
$10,000 \leq \mathrm{ES}<15,000$ & 190 & 11 & 17 \\
$2000 \leq \mathrm{ES}<10,000$ & 486 & 78 & 112 \\
$\mathrm{ES}<2000$ & 767 & 401 & 185 \\
Total & & 420 & 347 \\
\hline
\end{tabular}

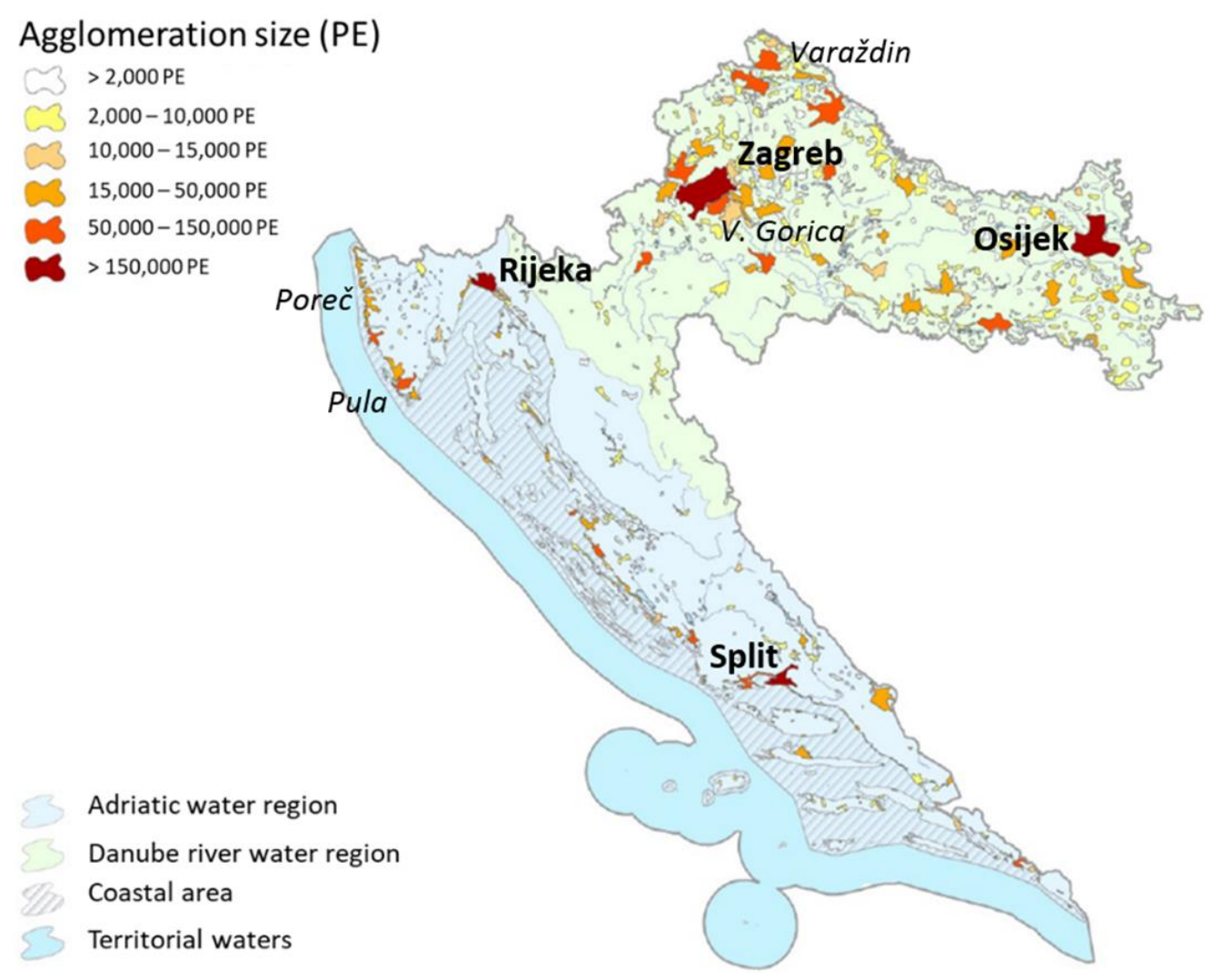

Figure 3. Spatial arrangement of agglomerations in Croatia.

\subsection{Sewage Sludge Treatment in Croatia}

Over the last decade, Croatia has been producing around 20,000 tonnes of sewage sludge per year (Figure 4). The total quantity of sewage sludge was 21,366 tonnes DM in 2016. The WWTP in Zagreb produces about $70 \%$ of the total sludge quantity in Croatia. In the EU, the annual sewage 
sludge production per population equivalent served by wastewater treatment is between 20 and $35 \mathrm{~kg}_{\mathrm{DM}} / \mathrm{PE}$ [38], while in Croatia it is $20-25 \mathrm{~kg}$ DM $/ \mathrm{PE}$ [35].

The quantity of sewage sludge is expected to increase multifold over the next years, following the planned extensive upgrades in the public wastewater system. According to the estimates of the national water service company [35], sewage sludge production will surpass 100,000 tonnes DM by 2024.

At present, WWTPs in Croatia have individual approaches to sewage sludge management and disposal. The WWTP Zagreb uses long-term storage as an intermediate solution prior to the construction of a mono-incineration plant. As for the long-term solution, mono-incineration is emerging as the preferred solution. The proposal is to build mono-incineration plants in the four major cities of Croatia (Zagreb, Split, Rijeka, and Osijek), which would incinerate the sewage sludge collected from smaller WWTPs in the surrounding regions. Until then, landfilling, recycling in agriculture, and co-incineration in waste incineration plants and cement factories is the short-term solution.

The practice of sludge recycling in agriculture is recently experiencing increasing public disapproval and will most likely be abandoned in the future. In Croatia, the quantity of sewage sludge used in agriculture was 1290 tonnes DM in 2017, representing 6\% of the total quantity of produced sludge. More than $70 \%$ of that quantity is mixed with biomass waste (leaves, grass, branches, etc.) and stored for composting before application on land. In Croatia, the application of sewage sludge on land must be in line with specific regulations and standards. Following the guidelines of the Sewage Sludge Directive (86/278/EEC), recycling in agriculture is allowed only for treated and stabilized sludge, while respecting the limit values of concentrations for heavy metals and organic pollutants [39].

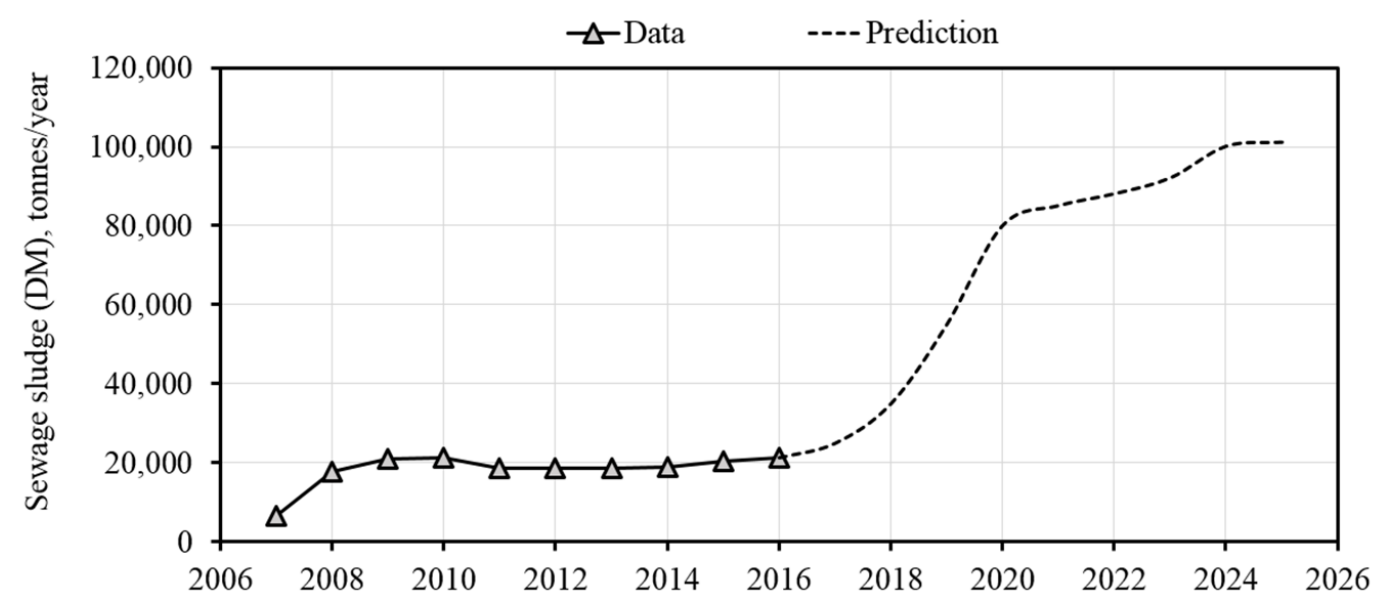

Figure 4. Quantity of sewage sludge produced in Croatia, data for 2007-2016 and predictions to 2025. Data from [35].

\section{Analysis and Results}

\subsection{The Wastewater Treatment Plant Zagreb}

The WWTP Zagreb, which is the largest city and capital of Republic of Croatia, has a design capacity of 1.2 million PE and implements secondary wastewater treatment with planned upgrade to tertiary treatment with phosphorus and nitrogen removal. The WWTP Zagreb generates around 15,000 tonnes DM of sewage sludge per year. Sewage sludge is stabilized for a period of 18 days in four AD units with total volume of $35,360 \mathrm{~m}^{3}$, shown in Figure 5. The anaerobic process is enhanced by sludge mixing and heating during mesophilic conditions $\left(37^{\circ} \mathrm{C}\right)$. Sludge stabilization converts around $50 \%$ of the organic matter into water, carbon dioxide $\left(\mathrm{CO}_{2}\right)$, and biogas with a methane content of $60 \%$. The heating value of raw sludge is $13 \mathrm{MJ} / \mathrm{kg}_{\mathrm{DM}}$ and that of stabilized sludge $9 \mathrm{MJ} / \mathrm{kg}_{\mathrm{DM}}$ [40]. The average production of biogas is $7.3 \mathrm{~m}^{3} / \mathrm{PE}$ per year and its heating value is $20 \mathrm{MJ} / \mathrm{m}^{3}$. Biogas fuels a CHP system with an installed electrical capacity of $2.6 \mathrm{MW}$, at an electrical efficiency of $38 \%$ and a 
thermal efficiency of $50 \%$. The specific electricity consumption is $30 \mathrm{kWh}_{\mathrm{e}} / \mathrm{PE}$ and the CHP system supplies around $60 \%$ of the electricity to the WWTP.

The thermal energy, on the other hand, is used for the heating of AD units. Stabilized sludge is treated with polymers and lime before centrifugal dewatering. The DM content in the dewatered sludge is at least $30 \%$. The largest part of the produced sewage sludge is stored in long-term storages at the plant location while smaller quantities are applied to agricultural surfaces or transported to cement kilns and incineration plants. At present, local authorities are considering the construction of a mono-incineration plant because more than 150,000 tonnes DM of sewage sludge is stored and awaiting final disposal. Data from the WWTP Zagreb shows that the energy potential of biogas is 146 $\mathrm{MJ} / \mathrm{PE}$ per year and that of sewage sludge DM is $113 \mathrm{MJ} / \mathrm{PE}$ per year.

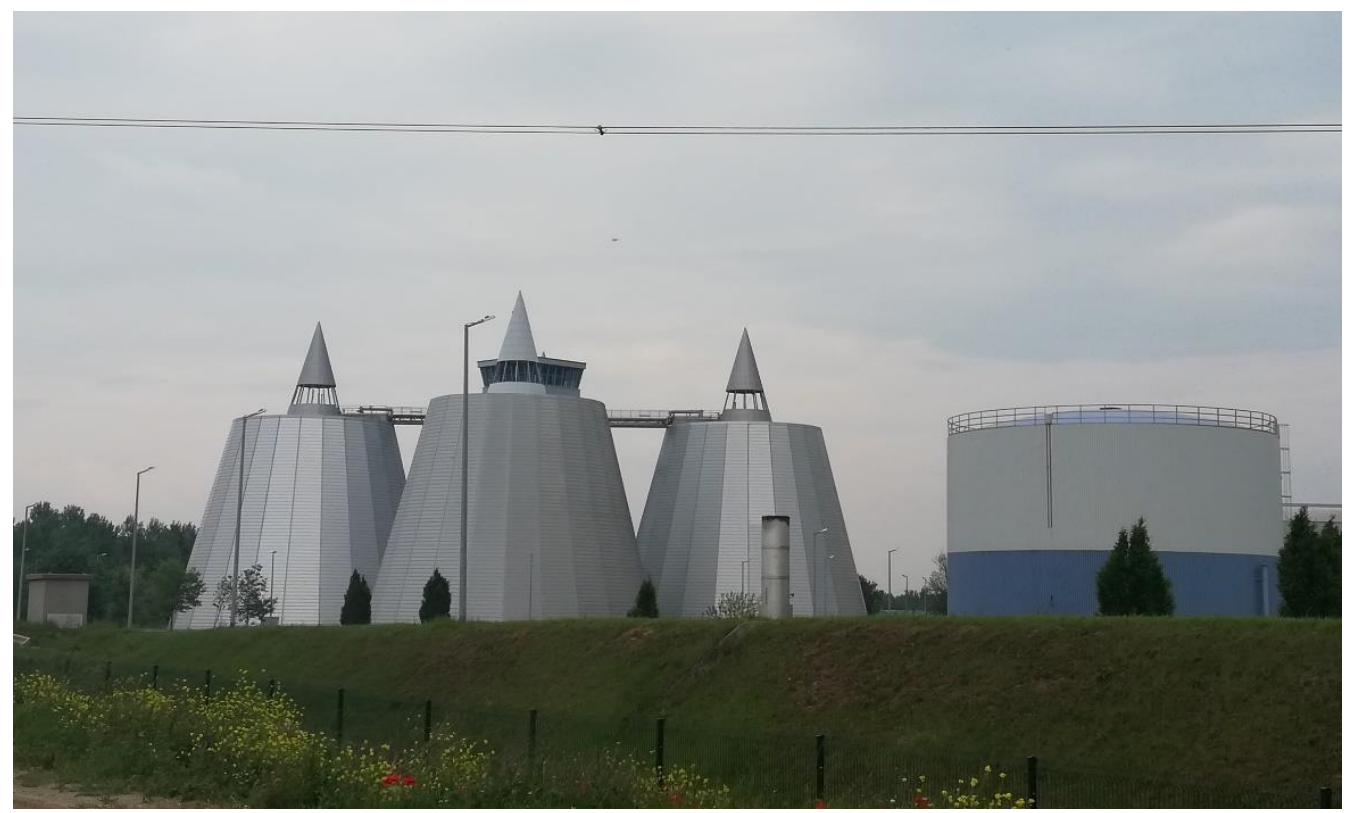

Figure 5. The anaerobic digesters of the WWTP Zagreb.

\subsection{Future Wastewater Treatment Projects}

Croatia is considering different management strategies for the treatment and disposal of sewage sludge. Croatia counts 281 agglomerations larger than $2000 \mathrm{PE}$, with a total population of 3.5 million inhabitants and a cumulative wastewater load of 5 million PE. Larger WWTPs (PE > 80,000) will most likely use anaerobic stabilization with subsequent drying and incineration of sewage sludge. Smaller WWTPs, on the other hand, will choose between several variants. In the first variant, when larger WWTPs are close, transport of sewage sludge is seen as an acceptable solution. Further sludge stabilization is performed at the sites of the larger WWTPs. In the second variant, when larger WWTPs are too distant, transport is not justified, and sludge stabilization is performed at the site of the smaller plant. In this case, sludge stabilization includes homogenization and dewatering, or aerobic processes followed by mechanical drying (thickening and dewatering).

Table 3 shows the design hydraulic loads, average physicochemical loads and the expected quantities of the by-products of wastewater treatment in seven selected WWTP projects. These seven WWTPs projects include five major agglomerations with constant wastewater loads and two minor agglomerations with variable wastewater loads due to tourism activity. The specific daily loads are between 90 and $130 \mathrm{~L} / \mathrm{PE}$ of wastewater, 9 and $11 \mathrm{~g} / \mathrm{PE}$ of nitrogen, and 1.6 and $2.0 \mathrm{~g} / \mathrm{PE}$ of phosphorus. The $\mathrm{BOD}_{5}$-to-COD ratio is between 0.4 and 0.5 , which is typical for biologically-degradable domestic wastewaters. In Croatia, the specific annual quantities of sewage sludge and biogas yield are 20-25 $\mathrm{kg}_{\mathrm{DM}} / \mathrm{PE}$ and $5.8-7.3 \mathrm{~m}^{3} / \mathrm{PE}$. For comparison, in the EU, the specific quantities are 20-35 $\mathrm{kg}_{\mathrm{DM}} / \mathrm{PE}$ [38] and 6.6-9.5 m³ $/ \mathrm{PE}$, respectively [41]. 
Table 3. Wastewater properties in the planned WWTPs in Croatia (data obtained from environmental studies of specific WWTP).

\begin{tabular}{|c|c|c|c|c|c|c|c|c|}
\hline \multirow{2}{*}{\multicolumn{2}{|c|}{ WWTP }} & \multirow{2}{*}{ Split } & \multirow[b]{2}{*}{ Rijeka } & \multirow{2}{*}{ Osijek } & \multirow[b]{2}{*}{ Varaždin } & \multirow{2}{*}{$\begin{array}{l}\text { Velika } \\
\text { Gorica }\end{array}$} & \multicolumn{2}{|c|}{ Pula-Nord } \\
\hline & & & & & & & Low & High \\
\hline \multicolumn{2}{|l|}{ Capacity, PE } & 275,000 & 200,000 & 170,000 & 127,000 & 74,000 & 13,264 & 58,000 \\
\hline \multicolumn{9}{|c|}{ Hydraulic Load } \\
\hline \multicolumn{2}{|c|}{ Domestic wastewater, $\mathrm{m}^{3} / \mathrm{d}$} & $\mathrm{n} / \mathrm{a}$ & 18,060 & 14,700 & $\mathrm{n} / \mathrm{a}$ & 6876 & 1715 & 7000 \\
\hline \multicolumn{2}{|c|}{ Industrial wastewater, $\mathrm{m}^{3} / \mathrm{d}$} & $\mathrm{n} / \mathrm{a}$ & 9754 & 7950 & $\mathrm{n} / \mathrm{a}$ & 1749 & 0 & 0 \\
\hline \multicolumn{2}{|c|}{ Total wastewater, $\mathrm{m}^{3} / \mathrm{d}$} & 34,650 & 27,814 & 22,650 & 19,849 & 8625 & 1715 & 7000 \\
\hline \multicolumn{2}{|l|}{ Infiltration, $\mathrm{m}^{3} / \mathrm{d}$} & 14,850 & 8241 & 11,350 & 11,909 & 3434 & 744 & 3000 \\
\hline \multicolumn{2}{|c|}{ Total hydraulic load, $\mathrm{m}^{3} / \mathrm{d}$} & 49,500 & 36,055 & 34,000 & 31,758 & 12,059 & 2459 & 10,000 \\
\hline \multicolumn{9}{|c|}{ Physicochemical Load } \\
\hline \multirow{2}{*}{$\begin{array}{l}\text { Chemical oxygen } \\
\text { demand (COD) }\end{array}$} & $\mathrm{mg} / \mathrm{L}$ & 658 & 698 & 633 & 540 & 791 & 647 & 696 \\
\hline & $\mathrm{kg} / \mathrm{d}$ & 32,571 & 25,176 & 21,522 & 17,147 & 9538 & 1592 & 6960 \\
\hline \multirow{2}{*}{$\begin{array}{l}\text { Biochemical oxygen } \\
\text { demand (BOD } 5 \text { ) }\end{array}$} & $\mathrm{mg} / \mathrm{L}$ & 329 & 304 & 300 & 240 & 368 & 324 & 348 \\
\hline & $\mathrm{kg} / \mathrm{d}$ & 16,286 & 10,968 & 10,200 & 7616 & 4438 & 796 & 3480 \\
\hline \multirow{2}{*}{$\begin{array}{l}\text { Total suspended } \\
\text { solids (TSS) }\end{array}$} & $\mathrm{mg} / \mathrm{L}$ & 384 & 442 & 350 & 293 & 491 & 378 & 406 \\
\hline & $\mathrm{kg} / \mathrm{d}$ & 19,008 & 15,946 & 11,900 & 9310 & 5919 & 928 & 4060 \\
\hline \multirow{2}{*}{ Total nitrogen $(\mathrm{N})$} & $\mathrm{mg} / \mathrm{L}$ & 60 & 53 & 55 & 39 & 64 & 59.3 & 63.8 \\
\hline & $\mathrm{kg} / \mathrm{d}$ & 2970 & 1898 & 1870 & 1244 & 777 & 146 & 638 \\
\hline \multirow{2}{*}{ Total phosphorous (P) } & $\mathrm{mg} / \mathrm{L}$ & 10 & 9 & 9 & 7.8 & 11 & 9.7 & 10.4 \\
\hline & $\mathrm{kg} / \mathrm{d}$ & 495 & 331 & 306 & 249 & 131 & 23.9 & 104 \\
\hline \multicolumn{9}{|c|}{ Technologies } \\
\hline \multirow{3}{*}{\multicolumn{2}{|c|}{$\begin{array}{l}\text { Planned treatment stage } \\
\text { Sludge stabilization * } \\
\text { Flectricity }\end{array}$}} & Secondary & Secondary & Tertiary & Tertiary & Tertiary & \multirow{2}{*}{\multicolumn{2}{|c|}{ Secondary }} \\
\hline & & AND & AND & AND & AND & AND & & \\
\hline & & 37.2 & 46.6 & 43.1 & 40.2 & 47.6 & \multicolumn{2}{|c|}{$\begin{array}{l}\text { AD } \\
43.5\end{array}$} \\
\hline \multicolumn{9}{|c|}{ By-Products } \\
\hline \multicolumn{2}{|l|}{ Sewage sludge, $t / y$} & 6500 & 5120 & 3450 & 3285 & 1661 & \multicolumn{2}{|c|}{645} \\
\hline \multicolumn{2}{|l|}{ Debris and grit, $t / y$} & $\mathrm{n} / \mathrm{a}$ & 1400 & 1200 & 902 & 500 & \multicolumn{2}{|c|}{164} \\
\hline Sand, $t / y$ & & $\mathrm{n} / \mathrm{a}$ & 634 & 540 & 451 & 750 & & \\
\hline Grease, $t / y$ & & $\mathrm{n} / \mathrm{a}$ & 372 & 310 & 262 & 250 & & \\
\hline Biogas, $\mathrm{m}^{3} / \mathrm{y}(\times 1000$ & & 1600,000 & 1170,000 & 1022,000 & 931,000 & 533,000 & & \\
\hline
\end{tabular}

*AND = Anaerobic Digestion, $\mathrm{AD}=$ Aerobic Digestion.

\subsection{Energy Recovery from Sewage Sludge}

Sewage sludge exhibits variable composition and component concentrations. Sewage sludge contains organic substances, heavy metals, pathogens, and nutrients, such as nitrogen and phosphorous. The heavy metals found in sewage sludge are from anthropogenic sources. Manganese, lead, zinc, and copper are among the most represented heavy metals. Table 4 shows the composition of stabilized sewage sludge from the WWTP in Zagreb [42] and a comparison with the average composition of stabilized sewage sludge in German WWTPs [2]. The heating value of the DM is around $10 \mathrm{MJ} / \mathrm{kg}$, which makes sewage sludge a suitable fuel for energy generation. WWTPs produce sewage sludge with DM contents of around $30 \%$ and additional drying is necessary for energy recovery in incineration plants.

In Croatia, large WWTPs will be equipped with anaerobic stabilization of sewage sludge in order to produce valuable biogas. The biogas yield is between 190 and $240 \mathrm{Nm}^{3} / \mathrm{t}$ of organic dry matter (ODM), under optimum anaerobic conditions. Between 45 and $55 \%$ of the organic matter is converted into biogas, which reduces the amount of sludge DM by 25-33\% [41]. The composition of biogas depends on the conditions of the stabilization process and on the sewage sludge properties. Biogas contains mainly methane and carbon dioxide while water vapour, ammonia, and hydrogen sulphide are present in smaller concentrations. Hydrogen sulphide, ammonia, and water vapour, as well as other corrosive trace elements (siloxanes), are removed from biogas before its use in CHP units. The properties of biogas from WWTPs in Croatia are given in Table 5. 
Table 4. Composition of sewage sludge in WWTPs in Zagreb and Germany. Data from [2,42].

\begin{tabular}{|c|c|c|c|}
\hline Parameter & WWTP Zagreb & WWTPs Germany & Unit \\
\hline Dry matter & $29.5-34.8$ & 30.5 & $\%$ \\
\hline Volatile matter & n.a. & 30 & $\%$ \\
\hline Heating value & $8.2-9.1$ & $10-12$ & $\mathrm{MJ} / \mathrm{kg}_{\mathrm{DM}}$ \\
\hline $\mathrm{pH}$-value & $11.6-12.9$ & 7.7 & - \\
\hline Organic matter & n.a. & $45-80$ & $\% \mathrm{DM}$ \\
\hline Carbon, C & $145-188$ & $330-500$ & $\mathrm{~g} / \mathrm{kg}_{\mathrm{DM}}$ \\
\hline Oxygen, $\mathrm{O}$ & n.a. & 100-200 & $\mathrm{g} / \mathrm{kg}_{\mathrm{DM}}$ \\
\hline Hydrogen, $\mathrm{H}$ & n.a. & $30-40$ & $\mathrm{~g} / \mathrm{kg}_{\mathrm{DM}}$ \\
\hline Nitrogen, $N$ & $26.0-35.1$ & $20-60$ & $\mathrm{~g} / \mathrm{kg}_{\mathrm{DM}}$ \\
\hline Phosphorus, $\mathrm{P}$ & $21.5-30.8$ & $2-55$ & $\mathrm{~g} / \mathrm{kg}_{\mathrm{DM}}$ \\
\hline Magnesium, $\mathrm{Mg}$ & n.a. & 9.17 & $\mathrm{~g} / \mathrm{kg}_{\mathrm{DM}}$ \\
\hline Potassium, K & n.a. & 2.63 & $\mathrm{~g} / \mathrm{kg}_{\mathrm{DM}}$ \\
\hline Calcium, $\mathrm{Ca}$ & n.a. & 71 & $\mathrm{~g} / \mathrm{kg}_{\mathrm{DM}}$ \\
\hline Cadmium, $\mathrm{Cd}$ & $<2$ & $1.5-4.5$ & $\mathrm{mg} / \mathrm{kg}_{\mathrm{DM}}$ \\
\hline Chromium, $\mathrm{Cr}$ & $22.5-31.1$ & $50-80$ & $\mathrm{mg} / \mathrm{kg}_{\mathrm{DM}}$ \\
\hline Zinc, Zn & $526-711$ & $100-300$ & $\mathrm{mg} / \mathrm{kg}_{\mathrm{DM}}$ \\
\hline Lead, $\mathrm{Pb}$ & $62.1-74.1$ & $70-100$ & $\mathrm{mg} / \mathrm{kg}_{\mathrm{DM}}$ \\
\hline Copper, $\mathrm{Cu}$ & $180-496$ & $300-350$ & $\mathrm{mg} / \mathrm{kg}_{\mathrm{DM}}$ \\
\hline Nickel, Ni & 26.5-31.1 & $30-35$ & $\mathrm{mg} / \mathrm{kg}_{\mathrm{DM}}$ \\
\hline Cobalt, Co & $9.8-11.9$ & 6.53 & $\mathrm{mg} / \mathrm{kg}_{\mathrm{DM}}$ \\
\hline Mercury, Hg & $1.01-1.52$ & $0.3-2.5$ & $\mathrm{mg} / \mathrm{kg}_{\mathrm{DM}}$ \\
\hline Arsenic, As & $11.95-16.01$ & $4-30$ & $\mathrm{mg} / \mathrm{kg}_{\mathrm{DM}}$ \\
\hline Antimony, $\mathrm{Sb}$ & n.a. & $5-30$ & $\mathrm{mg} / \mathrm{kg}_{\mathrm{DM}}$ \\
\hline Manganese, Mn & n.a. & $600-1500$ & $\mathrm{mg} / \mathrm{kg}_{\mathrm{DM}}$ \\
\hline Molybdenum, Mo & $2.42-3.02$ & 3.9 & $\mathrm{mg} / \mathrm{kg}_{\mathrm{DM}}$ \\
\hline Tin, Sn & n.a. & $30-80$ & $\mathrm{mg} / \mathrm{kg}_{\mathrm{DM}}$ \\
\hline Vanadium, V & n.a. & 10-100 & $\mathrm{mg} / \mathrm{kg}_{\mathrm{DM}}$ \\
\hline
\end{tabular}

The total wastewater treatment capacity in Croatia is estimated at 4.1 million PE in over 200 WWTPs. The six major WWTPs in Croatia (Zagreb, Split, Rijeka, Osijek, Varaždin, and Velika Gorica) will have an overall capacity of about 2 million PE, after the planned upgrades. The expected annual quantities of sewage sludge and biogas produced in these six WWTPs are 35,000 tonnes DM and 14 million $\mathrm{m}^{3}$, respectively. These quantities of sewage sludge and biogas return specific annual production rates of $17.5 \mathrm{~kg} / \mathrm{PE}$ of sewage sludge and $7.0 \mathrm{~m}^{3} / \mathrm{PE}$ of biogas, on average.

Biogas from anaerobic sludge stabilization is subject to variable composition with methane concentrations as low as $40 \%$. Generally, biogas is used to fuel internal combustion engines. Biogas engines are marketed with capacities in the range between $10 \mathrm{~kW}_{\mathrm{el}}$ and $5 \mathrm{MW}_{\mathrm{el}}$. They achieve overall efficiencies of up to $90 \%$, whereas the electrical efficiency is $35 \%$, the thermal efficiency $55 \%$, and the losses 10\% [41,43]. Incineration units are not efficient as CHP units. They achieve overall efficiencies of around $80 \%$, where the electrical efficiency is $20 \%$ [44] and thermal efficiency $60 \%$ [45].

Taking that the average biogas heating value is $21.6 \mathrm{MJ} / \mathrm{m}^{3}\left(6.0 \mathrm{kWh} / \mathrm{m}^{3}\right), \mathrm{CHP}$ units generate $2.1 \mathrm{kWh} / \mathrm{e} / \mathrm{m}^{3}$ of electricity and $3.3 \mathrm{kWh}$ th $/ \mathrm{m}^{3}$ of heat per unit of biogas. The generated electricity is used by the WWTP or fed to the grid, possibly under subsidized tariff systems. Estimates for the total energy consumption in the major Croatian WWTPs are in the range between 0.55 and $0.9 \mathrm{kWh} / \mathrm{m}^{3}$ of treated wastewater (45-80 kWh/PE). These energy consumptions correspond to WWTPs with secondary wastewater treatment, activated sludge process, and AD of sewage sludge. The electricity consumption is between 0.35 and $0.55 \mathrm{kWh} \mathrm{el}_{\mathrm{e}} / \mathrm{m}^{3}$ of treated wastewater (30-50 $\left.\mathrm{kWh} / \mathrm{PE}\right)$. The thermal energy consumption is between 0.15 and $0.35 \mathrm{kWh}$ th $/ \mathrm{m}^{3}$ of treated wastewater $\left(15-30 \mathrm{kWh}_{\mathrm{th}} / \mathrm{PE}\right)$. Generally, the specific energy consumption of the WWTP decreases as its size and capacity increase.

The major electricity consumers in WWTPs are aeration, pumping, sludge thickening, and dewatering [1]. Taking that the biogas yield is in the range between 5.8 and $7.3 \mathrm{~m}^{3} / \mathrm{PE}$, the amount of 
electricity generated from biogas is $12-16 \mathrm{kWh}$ el $/ \mathrm{PE}$. Biogas $\mathrm{CHP}$ units will supply about $30 \%$ of the electricity demand of WWTPs in Croatia.

Table 5. Properties of biogas produced by anaerobic stabilization of sewage sludge.

\begin{tabular}{lcc}
\hline Parameter & Input & Unit \\
\hline Lower heating value & $20-25$ & $\mathrm{MJ} / \mathrm{m}^{3}$ \\
Explosion limit in air & $6-12$ & $\%$ \\
Self-ignition temperature & $650-750$ & ${ }^{\circ} \mathrm{C}$ \\
Critical pressure & $54-59$ & $\mathrm{bar}$ \\
Critical temperature & $224-242$ & $\mathrm{~K}$ \\
Density & $1.0-1.2$ & $\mathrm{~kg} / \mathrm{m}^{3}$ \\
\hline Biogas composition & & \\
-methane $\left(\mathrm{CH}_{4}\right)$ & $55-70$ & $\%$ \\
-carbon dioxide $\left(\mathrm{CO}_{2}\right)$ & $30-45$ & $\%$ \\
-hydrogen sulphide $\left(\mathrm{H}_{2} \mathrm{~S}\right)$ & $0.5-1.0$ & $\%$ \\
-ammonia $\left(\mathrm{NH}_{3}\right)$ & $0.05-0.10$ & $\%$ \\
-water vapour $\left(\mathrm{H}_{2} \mathrm{O}\right)$ & $1-5$ & $\%$ \\
\hline
\end{tabular}

The generated heat, on the other hand, is used for heating of digesters, sludge reactors, and office buildings. In the total amount of CHP heat, $50-60 \%$ is high-temperature heat (flue gases temperatures of $450-550{ }^{\circ} \mathrm{C}$ ) and $40-50 \%$ is low-temperature heat (engine cooling fluid temperatures of $80-90{ }^{\circ} \mathrm{C}$ ). The amount of available biogas heat is $19.1-24.1 \mathrm{kWh}_{\mathrm{th}} / \mathrm{PE}$, which results with $80-100 \%$ thermal self-sufficiency. For example, the WWTP in Zagreb uses state-of-the-art wastewater technologies and processes, which ensure average autonomies of $60 \%$ for electricity and $100 \%$ for heat.

Energy recovery of sewage sludge can be performed in mono-incineration or co-incineration plants. In Croatia, mono-incineration plants are expected to dispose the majority of the produced sludge in the future. Energy recovery systems in incineration plants achieve electrical efficiencies of $20 \%$ and thermal efficiency of $60 \%$. Sewage sludge with annual production rates of $20-25 \mathrm{~kg} \mathrm{DM} / \mathrm{PE}$ and heating values of $2.5 \mathrm{kWh} / \mathrm{kg}_{\mathrm{DM}}$ could be converted into $10-13 \mathrm{kWh}$ el $/ \mathrm{PE}$ of electricity and $30-38 \mathrm{kWh}$ th $/ \mathrm{PE}$ of heat. In total, biogas and sewage sludge could supply $20-30 \mathrm{kWh}_{\mathrm{el}} / \mathrm{PE}$ of electricity and $50-60 \mathrm{kWh}$ th $/ \mathrm{PE}$ of thermal energy to WWTPs, assuming that incineration plants are built at the same location. The energy autonomy of the WWTP would increase to about $60 \%$ for electricity and $100 \%$ of thermal energy, with excess heat available. Surely, drying of sewage sludge needs large amounts of energy, but the costs can be significantly reduced using solar energy or waste heat.

\subsection{Drying of Sewage Sludge}

Drying of dewatered sewage sludge consumes substantial amounts of heat. The amount of water removed during thermal drying, over a range of dry contents from $30-90 \%$, is $2.2 \mathrm{~kg}_{\mathrm{W}} / \mathrm{kg}_{\mathrm{DM}}$. Since the latent heat of evaporation of water is $2.5 \mathrm{MJ} / \mathrm{kg}_{\mathrm{W}}$, drying from $30-90 \% \mathrm{DM}$ has a minimum energy requirement of $5.5 \mathrm{MJ} / \mathrm{kg}_{\mathrm{DM}}$ or $1.5 \mathrm{kWh}$ th $/ \mathrm{kg}_{\mathrm{DM}}$.

However, available drying technologies have higher energy requirements, between 2.9 and $3.6 \mathrm{MJ} / \mathrm{kg}_{\mathrm{W}}$ per unit of evaporated water. Thus, the thermal energy consumption for drying of sewage sludge to fuel-grade quality is between 1.8 and $2.2 \mathrm{kWh}_{\mathrm{th}} / \mathrm{kg}_{\mathrm{DM}}$. In addition to heat, the electricity consumption of the drying equipment is between 0.10 and $0.30 \mathrm{kWh} / \mathrm{kg}$ DM.

The energy efficiency between waste heat recovery from sewage sludge incineration and thermal drying is questionable. The energy balance of drying and incineration $\left(Q_{\mathrm{EB}}\right)$ can be calculated as the difference between waste heat recovery $\left(Q_{\mathrm{HR}}\right)$ and drying energy $\left(Q_{\mathrm{DE}}\right)$ :

$$
Q_{\mathrm{EB}}=Q_{\mathrm{HR}}-Q_{\mathrm{DE}}
$$


The quantity of recovered waste heat depends on the heat recovery efficiency $(\eta)$ and the lower heating value of sewage sludge (LHV), which can be predicted from the organic dry matter content $(\mathrm{ODM})$ and the dry matter content $\left(\mathrm{DM}_{2}\right)$ as proposed by Komilis et al. [46]:

$$
Q_{\mathrm{HR}}=\eta \cdot L H V=\eta \cdot\left[6.0 \cdot \mathrm{ODM}-4.9 \cdot\left(1-D M_{2}\right)\right], \mathrm{kWh} / \mathrm{kg}_{\mathrm{DM}}
$$

The drying energy depends on the amount of removed water, which can be determined from the dry matter contents before $\left(D M_{1}\right)$ and after $\left(D M_{2}\right)$ thermal drying. Assuming a specific energy consumption for drying of $3.27 \mathrm{MJ} / \mathrm{kg}_{\mathrm{W}}$ or $0.9 \mathrm{kWh} \mathrm{th}_{\mathrm{th}} / \mathrm{kg}_{\mathrm{W}}$, the drying energy is:

$$
Q_{\mathrm{DE}}=0.9 \cdot\left(\frac{1}{D M_{1}}-\frac{1}{D M_{2}}\right), \mathrm{kWh} / \mathrm{kg}_{\mathrm{DM}}
$$

Figure 6 depicts the energy balance with respect to the ODM and $D M_{2}$ values, assuming an energy recovery efficiency of $\eta=0.8$ and an initial dry matter content of $D M_{1}=0.3$. It can be seen that the energy balance is negative for sewage sludges with organic matter contents lower than ODM $<0.44$, regardless of the dry matter content after thermal drying $\left(D M_{2}\right)$. This is the case for digested sewage sludge with low heating values (LHV $<2.6 \mathrm{kWh} / \mathrm{kg}_{\mathrm{DM}}$ ).

On the other hand, the energy balance is positive over the entire range of $D M_{2}$ for sludges with high organic content (ODM $>0.66)$. This is the case for non-digested sewage sludge with high heating values (LHV $>4.0 \mathrm{kWh} / \mathrm{kg}_{\mathrm{DM}}$ ). In the range of $0.44<\mathrm{ODM}<0.57$, which corresponds to heating values between $2.6<\mathrm{LHV}<3.4 \mathrm{kWh} / \mathrm{kg}_{\mathrm{DM}}$, positive energy balance is obtained with thermal drying. For example, sewage sludge with $\mathrm{ODM}=0.5\left(\mathrm{LHV}=3 \mathrm{kWh} / \mathrm{kg}_{\mathrm{DM}}\right)$, is energy-positive with drying to dry matter contents of $D M_{2}>0.9$. Positive energy balance, not involving thermal drying $\left(D M_{2}=D M_{1}=0.3\right)$, can be achieved for ODM $>0.57$. In this case, sewage sludge achieves self-sustained combustion ( $\mathrm{LHV}>3.4 \mathrm{kWh} / \mathrm{kg}_{\mathrm{DM}}$ ) and its water content is evaporated by the produced heat.

The larger WWTPs in Croatia will implement AD technology, thus giving advantage to biogas energy rather than to that of sewage sludge. On the other hand, thermal disposal of digested sewage sludge is encumbered by low heating values ( $\left.\mathrm{LHV}=2-3 \mathrm{kWh} / \mathrm{kg}_{\mathrm{DM}}\right)$ and high-water contents $(70-80 \%)$. Thermal drying and waste heat recovery from incineration plants will be necessary prior to thermal disposal of sewage sludge. Recently, solar drying has received increasing attention, although its capacity is much lower than that of conventional drying. In Germany, for example, the annual capacity of solar drying is 350 tonnes of DM on average while fluidized beds, belt drying, and drum drying have capacities between 3000 and 5000 tonnes DM [2]. The solar drying capacity can be increased to around 1000 tonnes DM using waste heat from incineration plants or thermal power plants. Solar drying is performed inside heated and well-ventilated greenhouses [47]. Continuous turning and spreading of sewage sludge is needed to achieve dry matter contents of $75-80 \%$.

The evaporation potential in Croatia is estimated using the Penman-Monteith monthly method [48]. The annual evaporation potential is between 900 and $1500 \mathrm{~kg} / \mathrm{m}^{2}$ year. When drying sewage sludge from $0.30-0.75 \mathrm{DM}$ content, the necessary water removal is $2 \mathrm{~kg} / \mathrm{kg}_{\mathrm{DM}}$. Thus, the specific capacity of solar drying in Croatia is between 450 and $750 \mathrm{~kg} \mathrm{DM} / \mathrm{m}^{2}$ year.

Table 6 shows the surface requirements for solar drying in the four major WWTPs in Croatia. Despite low production capacities and large space requirements, solar drying is considered sustainable and economical, especially in regions with favourable climate. In Croatia, solar drying of sewage sludge is expected to become an integral part of the future wastewater treatment system. Solar dryers will operate as intermediate stations between WWTPs and incineration plants, providing drying and short-term storage. It is estimated that 50 solar dryers would be sufficient in Croatia. The annual production of sewage sludge is expected to reach 100,000 tonnes DM after the planned upgrades and expansions in the wastewater treatment system. If all of the produced sewage sludge is to be dried in 50 solar dryers, then the surface of one solar dryer should be $3300 \mathrm{~m}^{2}$ on average. 


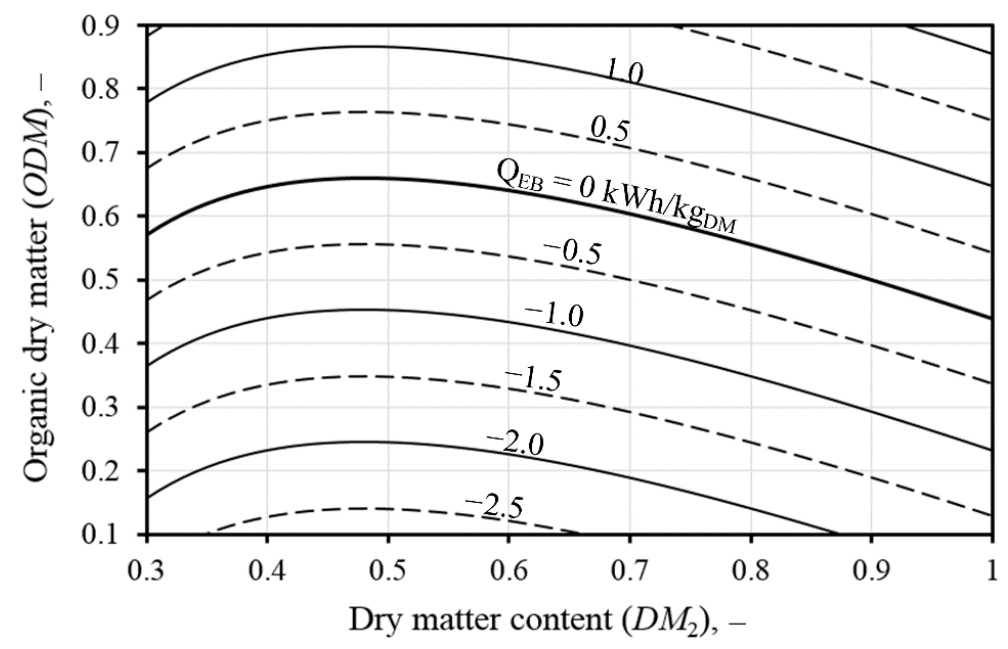

Figure 6. Energy balance between waste heat recovery and thermal drying of sewage sludge.

Table 6. Surface requirements for solar drying of sewage sludge in Croatian WWTPs.

\begin{tabular}{ccccc}
\hline WWTP & $\begin{array}{c}\text { Sewage Sludge } \\
\text { Quantity }\left[\mathbf{t}_{\text {DM }} / \text { year }\right]\end{array}$ & $\begin{array}{c}\text { Evaporation Potential } \\
{\left[\mathbf{k g}_{\mathbf{W}} / \mathbf{m}^{\mathbf{2}} \mathbf{y e a r}\right]}\end{array}$ & $\begin{array}{c}\text { Sludge Solar Drying } \\
\text { Capacity }\left[\mathbf{k g} \mathbf{D M} / \mathbf{m}^{\mathbf{2}} \mathbf{y e a r}\right]\end{array}$ & $\begin{array}{c}\text { Solar Drying } \\
\text { Surface }\left[\mathbf{m}^{\mathbf{2}}\right]\end{array}$ \\
\hline Zagreb & 15,000 & 1115 & 558 & 26,900 \\
Split & 6500 & 1523 & 762 & 8500 \\
Rijeka & 5120 & 1297 & 649 & 7900 \\
Osijek & 3450 & 919 & 460 & 7500 \\
\hline
\end{tabular}

\subsection{Disposal of Incinerated Sewage Sludge Ash (ISSA)}

Although the volume of sewage sludge is reduced by $90 \%$ during incineration, ISSA is produced as by-product. ISSA contains inorganic compounds such as oxides of silicon $\left(\mathrm{SiO}_{2}\right)$, calcium $(\mathrm{CaO})$, iron $\left(\mathrm{Fe}_{2} \mathrm{O}_{3}\right)$, aluminium $\left(\mathrm{Al}_{2} \mathrm{O}_{3}\right)$, phosphorus $\left(\mathrm{P}_{2} \mathrm{O}_{5}\right)$, sulphur $\left(\mathrm{SO}_{3}\right)$, magnesium $(\mathrm{MgO})$, and titanium $(\mathrm{TiO})$, but also unincinerated organic matter in smaller quantities [49]. ISSA can also contain heavy metals in traces, such as $\mathrm{Hg}, \mathrm{Cd}, \mathrm{As}, \mathrm{Sb}$, and $\mathrm{Pb}$. Therefore, ISSA requires appropriate treatment in order to prevent its harmful impact on the environment and human health. ISSA was recently considered as an additional material in the construction industry for concrete and cement [42], brick and asphalt production, or for the extraction of phosphorus, which is present in mass fraction of up to $10 \%$ [31].

In recent years, several technologies were developed for phosphorus recycling from ISSA, including pyrolytic processes and various wet processes. Pyrolytic processes partially remove metals from ash, but phosphorus remains in the form of insoluble apatite [50]. Apatite cannot be used by plants and has low value as fertilizer. In wet processes, acids or bases are added to ISSA, in order to dissolve phosphorus. Afterwards, phosphorous can be recovered through the precipitation of ammonium, calcium, sodium, iron, or aluminium phosphate, which are compounds identical to the ones found in mineral phosphate fertilizers.

\subsection{Avoided $\mathrm{CO}_{2}$ Emissions}

The avoided $\mathrm{CO}_{2}$ emissions by using sewage sludge as an energy source is analysed for the case of WWTP Rijeka. The annual quantity of sewage sludge produced in WWTP Rijeka is 5120 tonnes DM, with a heating value of around $10 \mathrm{MJ} / \mathrm{kg}$. The energy potential of this quantity of sewage sludge is $14,200 \mathrm{MWh}$, which exceeds the WWTP's thermal energy demand. Assuming that the electrical and thermal efficiency of the CHP are 30\% and 45\% [51], the energy content of sewage sludge could be converted into 4260 MWh of electricity and 6390 MWh of thermal energy.

In addition to its energy generation potential, another advantage of sewage sludge energy recovery is the reduction of GHG emissions, when compared against energy generation from fossil fuels. Sewage sludge is of organic origin and, according to IPCC recommendations [52], can be considered renewable 
energy source, which means that no direct $\mathrm{CO}_{2}$ emissions originate from energy generation. However, Chen and Kuo [51] calculated GHG emissions for different sewage sludge management scenarios and obtained $223 \mathrm{kgCO}_{2 \mathrm{eq}} / \mathrm{t}$ of indirect GHG emissions for incineration process. Therefore, the incineration of 5120 tonnes DM of sewage sludge would generate 1142 tonnes $\mathrm{CO}_{2 \mathrm{eq}}$ of indirect GHG emissions.

Compared to sewage sludge energy generation, a $\mathrm{CHP}$ unit on natural gas would originate around 2700 tonnes of $\mathrm{CO}_{2}$ emissions for the same amount of electricity and heat (Table 7).

Table 7. $\mathrm{CO}_{2}$ emissions from natural gas $\mathrm{CHP}$.

\begin{tabular}{ccc}
\hline Parameter & Value & Unit \\
\hline Electricity production & 4260 & $\mathrm{MWh}$ \\
Heat production & 6390 & $\mathrm{MWh}$ \\
Total efficiency of CHP plant & 80 & $\%$ \\
Total rated thermal input of natural gas & 48,000 & $\mathrm{GJ}$ \\
$\mathrm{CO}_{2}$ emissions factor for natural gas & 56.1 & $\mathrm{~kg} / \mathrm{GJ}$ \\
$\mathrm{CO}_{2}$ emissions from CHP plant & 2693 & $\mathrm{t}$ \\
\hline
\end{tabular}

Electricity generation from hard coal in thermal power plants and thermal energy from extra light fuel oil in district heating plants would originate over 5900 tonnes $\mathrm{CO}_{2}$ of emissions (Table 8). Taking into account both direct and indirect GHG emissions, energy generation from sewage sludge avoids around $1500 \mathrm{t}_{\mathrm{CO} 2}$ if compared to natural gas $\mathrm{CHP}$ and $4800 \mathrm{t}_{\mathrm{CO} 2}$ if compared to hard coal and fuel oil. Therefore, the reduction of GHG emissions obtained by energy generation from sewage sludge is $58 \%$ compared to natural gas and $80 \%$ compared to hard coal and fuel oil. Likewise biomass and biogas, sewage sludge is a renewable energy source, which contributes the reduction of GHG emissions and to the fulfilment of international agreements on climate change mitigation.

Table 8. $\mathrm{CO}_{2}$ emissions from hard coal and extra light fuel oil.

\begin{tabular}{ccc}
\hline Parameter & Value & Unit \\
\hline Electricity generation from hard coal & 4260 & $\mathrm{MWh}$ \\
Efficiency of thermal power plant & 36 & $\%$ \\
Total rated thermal input from hard coal & 42,667 & $\mathrm{GJ}$ \\
$\mathrm{CO}_{2}$ emissions factor for hard coal & 94.6 & $\mathrm{~kg} / \mathrm{GJ}$ \\
$\mathrm{CO}_{2}$ emissions from thermal power plant & 4036 & $\mathrm{t}$ \\
\hline Thermal energy generation from extra light fuel oil & 6390 & $\mathrm{MWh}$ \\
Efficiency of district heating & 90 & $\%$ \\
Total rated thermal input of extra light fuel oil & 25,600 & $\mathrm{GJ}$ \\
$\mathrm{CO}_{2}$ emissions factor for extra light fuel oil & 74.1 & $\mathrm{~kg} / \mathrm{GJ}$ \\
$\mathrm{CO}_{2}$ emissions from district heating & 1897 & $\mathrm{t}$ \\
\hline Total $\mathrm{CO}_{2}$ emissions & 5933 & $\mathrm{t}$ \\
\hline
\end{tabular}

\section{Discussion}

In Croatia, three scenarios for the management and treatment of sewage sludge can be considered: treatment in mono-incineration plants (TMP), treatment in cement plants (TCP), and the business-as-usual (BAU) scenario. In the BAU scenario, sewage sludge is treated by landfilling. Sludge is landfilled at current landfills and it is assumed that, in the future, it will be landfilled at regional waste management centres. According to [53], 10 waste management centres are predicted in Croatia, operational by 2023. The TCP scenario considers incineration of sewage sludge in cement plants. At present, cement plants in Croatia treat the refuse-derived fuel (RDF) from waste management centres and could also use the sewage sludge from WWTPs as a fuel and filler in cement production. Only three cement plants meet the necessary requirements for utilization of sewage sludge. The TMP scenario considers four mono-incineration plants in Zagreb, Split, Rijeka, and Osijek. These plants would accept the sewage sludge and utilize it for energy recovery. 
The three scenarios consider a total of 281 WWTPs larger than 2000 PE and take into account the costs and emissions from transport, but also the gate-fees for the three scenarios. The gate-fee for mono-incineration is assumed $100 € / t_{\mathrm{DM}}[54]$ and those for co-incineration and landfilling 30 and $62 € / t_{\mathrm{DM}}$ [55], respectively. The cost of transport is related to the size of the truck (up to $25 \mathrm{t}$ of capacity) and distance between destinations (up to $600 \mathrm{~km}$ ). Road transport with trucks is considered, whereas the emission levels are estimated from the Bilan Carbone model [56]. Table 9 presents the methodology for the three sludge treatment scenarios.

The three scenarios generate different amounts of $\mathrm{CO}_{2}$ emissions during sewage sludge treatment and disposal. It was estimated that sewage sludge incineration in cement plants and in mono-incineration plants generates $488.7 \mathrm{~kg} \mathrm{CO}_{\mathrm{eq}} / \mathrm{t}_{\mathrm{DM}}$ while landfilling generates $10.8 \mathrm{~kg}$ CO2eq $/ \mathrm{t}_{\mathrm{DM}}[2]$.

Table 10 presents the costs and emissions for the three possible scenarios applied to the 281 WWTPs larger than 2000 PE in Croatia. The analysis shows that landfilling (BAU scenario) is the most cost-effective option for sewage sludge management. This is due to lower transport costs, mainly because 10 waste management centres are planned across Croatia, compared against three cement plants (TCP scenario) and four mono-incineration plants (TMP scenario). Moreover, it can also be noticed that the BAU scenario has the lowest emission, especially for smaller WWTPs $(<10,000$ PE).

However, in the case of larger WWTPs (>150,000 PE), the TCP scenario has the lowest costs while the TMP scenario has the lowest emissions. The lowest costs in the TCP scenario are explained by the low gate-fee for incineration in cement plants while the lowest emissions are explained by the fact that mono-incineration plants are planned near the four largest cities in Croatia, thus reducing sewage sludge emissions from transport. For one part of medium sized WWTPs (15,000-150,000 PE) the BAU scenario is still the one with the lowest costs and emissions. Landfilling of sewage sludge will be banned in all EU countries by 2025. Therefore, thermal treatment methods such as incineration in cement plants or in mono-incineration are emerging as alternative options for sewage sludge disposal, especially for cities generating large amounts of sewage sludge.

Table 9. Parameters of the sewage sludge treatment scenarios.

\begin{tabular}{|c|c|c|c|c|}
\hline Scenario & Mono-Incineration & $\begin{array}{l}\text { Treatment in } \\
\text { Cement Plants }\end{array}$ & $\begin{array}{l}\text { Landfilling at Waste Management } \\
\text { Centres }\end{array}$ & Unit \\
\hline $\begin{array}{l}\text { Sewage sludge } \\
\text { treatment } \\
\text { facilities }\end{array}$ & $\begin{array}{l}\text { Zagreb, Split, Rijeka, } \\
\text { Osijek }\end{array}$ & $\begin{array}{l}\text { Koromačno, Kaštel } \\
\text { Sućurac, Našice }\end{array}$ & $\begin{array}{l}\text { Kaštijun, Marišćina, Babina Gora, } \\
\text { Piškornica, Orlovnjak, Šagulje, Biljane } \\
\text { Donje, Bikarac, Lučino, Zagreb }\end{array}$ & / \\
\hline Transport costs & \multicolumn{3}{|c|}{ trip cost per kilometre $\mathrm{x}$ number of trips per year } & $€ /$ year \\
\hline Gate-fee & 100 & 30 & 62 & $€ / t_{\mathrm{DM}}$ \\
\hline Emissions & \multicolumn{3}{|c|}{ kilometres per year $\mathrm{x}$ emission factor for specific truck } & $\mathrm{t}_{\mathrm{CO} 2} /$ year \\
\hline $\begin{array}{l}\text { Truck size (Bilan } \\
\text { Carbone model) }\end{array}$ & \multicolumn{3}{|c|}{$\begin{array}{c}\text { Different truck capacities are considered: } 0.46 \mathrm{t}, 0.70 \mathrm{t}, 1.24 \mathrm{t}, 1.40 \mathrm{t}, 2.37 \mathrm{t}, 2.84 \mathrm{t}, 4.69 \mathrm{t} \text {, } \\
9.79 \mathrm{t}, 11.62 \mathrm{t}, 16.66 \mathrm{t} \text { and } 25.0 \mathrm{t}\end{array}$} & l \\
\hline $\begin{array}{l}\text { Number of } \\
\text { trips/year }\end{array}$ & \multicolumn{3}{|c|}{ The amount of dried sewage sludge / truck capacity } & l \\
\hline
\end{tabular}

Table 10. Results of three scenarios (treatment in mono-incineration plants-TMP; treatment in cement plants-TCP; treatment in waste management centres-BAU).

\begin{tabular}{|c|c|c|c|c|c|c|}
\hline \multicolumn{2}{|c|}{ WWTP Size (PE) } & $2000-10,000$ & $10,000-15,000$ & $15,000-150,000$ & $>150,000$ & Total \\
\hline \multicolumn{2}{|c|}{ WWTP number } & 190 & 28 & 59 & 4 & 281 \\
\hline \multirow{3}{*}{$\begin{array}{l}\text { Lowest } \\
\text { costs }\end{array}$} & TMP & 0 & 0 & 0 & 0 & 0 \\
\hline & $\mathrm{CMP}$ & 67 & 10 & 32 & 4 & 113 \\
\hline & BAU & 123 & 18 & 27 & 0 & 168 \\
\hline \multirow{3}{*}{$\begin{array}{c}\text { Lowest } \mathrm{CO}_{2} \\
\text { emissions }\end{array}$} & TMP & 71 & 11 & 22 & 4 & 108 \\
\hline & $\mathrm{CMP}$ & 16 & 3 & 5 & 0 & 24 \\
\hline & BAU & 103 & 14 & 32 & 0 & 149 \\
\hline
\end{tabular}




\section{Conclusions}

The optimal solution for sewage sludge management depends on the expected quantities and sludge properties, the capital investment, the operational challenges and costs, the ecological and technological constraints, the legal and location restrictions, as well as on the chosen type of application or disposal of by-products. The fastest growing methods for sewage sludge treatment and disposal are anaerobic digestion and incineration. Incineration of sewage sludge has become more interesting lately because it significantly reduces the sludge volume and mass, destroys the harmful substances, and can be coupled to energy recovery systems. Nutrient recovery from wastewater and sewage sludge is also becoming increasingly important. Nutrient recovery from sewage sludge ash is more difficult and feasible only for ash with high concentrations of nutrients.

In Croatia, plans indicate that WWTPS larger than 100,000 PE will use sludge stabilization by anaerobic digestion with biogas production, followed by thickening and dewatering. It was estimated that biogas will supply $30-40 \%$ of the electricity needs and $80-100 \%$ of thermal energy needs to WWTPs in Croatia. On the other side, final disposal of sewage sludge is yet to be resolved. At the moment, mono-incineration is seen as the most promising technology. Mono-incineration plants are planned in the four major cities of Croatia. Energy recovery from sewage sludge incineration can be feasible if solar drying is used instead of conventional drying techniques. The capacity of solar dryers is estimated between 450 and $750 \mathrm{~kg} \mathrm{DM}_{\mathrm{m}} / \mathrm{m}^{2}$ year in Croatia, while a final dry matter content of $75-80 \%$ can be achieved. In that case, biogas generation and energy recovery from sewage sludge could supply $60 \%$ of the electricity and $100 \%$ of the thermal energy necessary for the operation of WWTPs.

Sewage sludge is of organic origin and is considered emission-neutral, according to IPCC guidelines. Compared to conventional energy generation from fossil fuels, sewage sludge emits $58 \%$ less GHG emissions than CHP units on natural gas and $80 \%$ less emissions than hard coal power plants and fuel oil district heating systems. This is a significant contribution to climate change mitigation policy and testifies that sewage sludge is a valuable source of renewable energy. Moreover, an analysis of three scenarios (landfilling, incineration in cement plants, and incineration in mono-incineration plants) was performed and showed that business-as-usual (landfilling) is still the cheapest solution, especially for small WWTPs. It should be taken into account that landfilling of biodegradable waste will be prohibited in the EU. Co-incineration and mono-incineration become increasingly interesting for larger WWTPs.

Regarding nutrients' recovery (phosphorus, nitrogen and potassium), effective and feasible techniques are necessary, especially if mono-incineration is to become the principal method for the final disposal of wastewater sludge.

Author Contributions: D.Đ. conceived the research and wrote the paper; P.B. analysed the data and wrote the paper; and Ž.J. validated the analysis, supervised the project and reviewed the paper.

Funding: This research received no external funding.

Conflicts of Interest: The authors declare no conflict of interest.

\section{References}

1. Joint Research Centre. Best Available Techniques (BAT) Reference Document for Waste Treatment; European Commission: Brussels, Belgium, 2017.

2. Wiechmann, B.; Dienemann, C.; Kabbe, C.; Brandt, S.; Vogel, I.; Roskosch, A. Sewage Sludge Management in Germany; Umweltbundesamt GVP: Bonn, Germany, 2013.

3. European Commission. Environmental, Economic and Social Impacts of the Use of Sewage Sludge on Land, Part I: Overview Report; European Commission: Brussels, Belgium, 2008.

4. Kelessidis, A.; Stasinakis, A.S. Comparative study of the methods used for treatment and final disposal of sewage sludge in European countries. Waste Manag. 2012, 32, 1186-1195. [CrossRef] [PubMed]

5. Campbell, M. Sludge management-Future issues and trends. Water Sci. Technol. 2000, 41, 1-8. [CrossRef] 
6. Kacprzak, M.; Neczaj, E.; Fijałkowski, K.; Grobelaka, A.; Grosser, A.; Worwag, M.; Rorat, A.; Brattebo, H.; Almås, Å.; Singh, B.R. Sewage sludge disposal strategies for sustainable development. Environ. Res. 2017, 156, 39-46. [CrossRef] [PubMed]

7. Yoshida, H.; Christensen, T.H.; Guildal, T.; Scheutz, C. A comprehensive substance flow analysis of a municipal wastewater and sludge treatment plant. Chemosphere 2015, 138, 874-882. [CrossRef]

8. Hadi, P.; Xu, M.; Ning, C.; Lin, C.S.K.; McKay, G. A critical review on preparation, characterization and utilization of sludge-derived activated carbons for wastewater treatment. Chem. Eng. J. 2015, 260, 895-906. [CrossRef]

9. Zhang, W.; Grimi, N.; Jaffrin, M.; Ding, L.; Tang, B.; Zhang, Z. Optimization of RDM-UF for alfalfa wastewater treatment using RSM. Environ. Sci. Pollut. Res. 2018, 25, 1439-1447. [CrossRef] [PubMed]

10. Mo, J.; Yang, Q.; Zhang, N.; Zhang, W.; Zheng, Y.; Zhang, Z. A review on agro-industrial waste (AIW) derived adsorbents for water and wastewater treatment. J. Environ. Manag. 2018, 227, 395-405. [CrossRef] [PubMed]

11. Mininni, G.; Blanch, A.; Lucena, F.; Berselli, S. EU policy on sewage sludge utilization and perspectives on new approaches of sludge management. Environ. Sci. Pollut. Res. 2015, 22, 7361-7374. [CrossRef] [PubMed]

12. Thevenon, F.; Graham, N.D.; Chiaradia, M.; Arpagaus, P.; Wildi, W.; Poté, J. Local to regional scale industrial heavy metal pollution recorded in sediments of large freshwater lakes in central Europe (lakes Geneva and Lucerne) over the last centuries. Sci. Total Environ. 2011, 412, 239-247. [CrossRef] [PubMed]

13. Spinosa, L.; Ayol, A.; Baudez, J.-C.; Canziani, R.; Jenicek, P.; Léonard, A.; Rulkens, W.; Xu, G.; Van Dijk, L. Sustainable and Innovative Solutions for Sewage Sludge Management. Water 2011, 3, 702-717. [CrossRef]

14. Mills, N.; Pearce, P.; Farrow, J.; Thorpe, R.; Kirkby, N. Environmental \& economic life cycle assessment of current \& future sewage sludge to energy technologies. Waste Manag. 2014, 34, 185-195. [PubMed]

15. Đurđević, D.; Blecich, P.; Lenić, K. Energy potential of digestate produced by anaerobic digestion in biogas power plants: the case study of Croatia. Environ. Eng. Sci. 2018, 35, 1286-1293. [CrossRef]

16. European Commission. Optimal Use of Biogas from Waste Streams. An Assessment of the Potential of Biogas from Digestion in the EU beyond 2020; European Commission: Brussels, Belgium, 2016.

17. EuroObserv'ER. Biogas Barometer; EuroObserv'ER: Frankfurt, Germany, 2017.

18. Fytili, D.; Zabaniotou, A. Utilization of sewage sludge in EU application of old and new methods-A review. Renew. Sustain. Energy Rev. 2008, 12, 116-140. [CrossRef]

19. Đurđević, D.; Balić, D.; Jurić, Ž. Socio-Economic Aspects in Satisfying Energy Demands by Different Technologies of Heat and Electricity Generation. Tech. Gaz. 2019, 26.

20. Stasta, P.; Boráň, J.; Bébar, L.; Stehlik, P.; Oral, J. Thermal processing of sewage sludge. Appl. Therm. Eng. 2006, 26, 1420-1426. [CrossRef]

21. Cao, Y.; Pawłowski, A. Sewage sludge-to-energy approaches based on anaerobic digestion and pyrolysis: Brief overview and energy efficiency assessment. Renew. Sustain. Energy Rev. 2012, 16, 1657-1665. [CrossRef]

22. Lumley, N.P.; Ramey, D.F.; Prieto, A.L.; Braun, R.J.; Cath, T.Y.; Porter, J.M. Techno-economic analysis of wastewater sludge gasification: A decentralized urban perspective. Bioresour. Technol. 2014, 161, 385-394. [CrossRef]

23. Di Fraia, S.; Massarotti, N.; Vanoli, L.; Costa, M. Thermo-economic analysis of a novel cogeneration system for sewage sludge treatment. Energy 2016, 115, 1560-1571. [CrossRef]

24. Johansson, K.; Perzon, M.; Fröling, M.; Mossakowska, A.; Svanström, M. Sewage sludge handling with phosphorus utilization-Life cycle assessment of four alternatives. J. Clean. Prod. 2008, 16, $135-151$. [CrossRef]

25. European Commission. Consultative Communication on the Sustainable Use of Phosphorus, COM (2013) 517 Final; European Commission: Brussels, Belgium, 2013.

26. Praspaliauskas, M.; Pedišius, N. A review of sludge characteristics in Lithuania's wastewater treatment plants and perspectives of its usage in thermal processes. Renew. Sustain. Energy Rev. 2017, 67, 899-907. [CrossRef]

27. Openshaw, K. Energy Values of Unprocessed Biomass, Charcoal and other Biomass Fuels and their role in Greenhouse Gas Mitigation and Energy Use. In Advances in Environmental Science and Energy Planning; WSEAS Press: Tenerife, Canary Islands, Spain, 2014; pp. 30-40.

28. Fuwape, J.A. Charcoal and fuel value of agroforestry tree crops. Agrofor. Syst. 1993, 22, 175-179. [CrossRef]

29. Republic of Poland. The National Urban Wastewater Treatment Program; Regulation of the Ministry of Environment: Warsaw, Poland, 2003. 
30. Stucki, M.; Eymann, L.; Gerner, G.; Hartmann, F.; Wanner, R.; Krebs, R. Hydrothermal carbonnization of sewage sludge on industrial scale: Energy efficiency, environmental effects and combustion. J. Energy Chall. Mech. 2015, 2, 38-44.

31. Donatello, S.; Cheeseman, C.R. Recycling and recovery routes for incinerated sewage sludge ash (ISSA): A review. Waste Manag. 2013, 33, 2328-2340. [CrossRef] [PubMed]

32. Lewis, M. Sludge pyrolysis for energy recovery and pollution control. In Proceedings of the National Conference on Municipal Treatment Plant Sludge Management, Anaheim, CA, USA, 18-20 August 1975.

33. Marrero, T.W.; McAuley, B.P.; Sutterlin, W.R.; Morris, J.S.; Manahan, S.E. Fate of heavy metals and radioactive metals in gasification of sewage sludge. Waste Manag. 2004, 24, 193-198. [CrossRef]

34. Luts, D.; Devoldere, K.; Laethem, B.; Bartholomeeusen, W.; Ockier, P. Co-incineration of dried sewage sludge in coal-fired power plants: A case study. Water Sci. Technol. 2000, 42, 259-268. [CrossRef]

35. Croatian Waters. Multiannual Programme of Municipal Water Building Construction 2014-2023; Croatian Waters: Zagreb, Croatia, 2014.

36. Croatian Bureau of Statistics. Statistical Yearbook of the Republic of Croatia 2017; Croatian Bureau of Statistics: Zagreb, Croatia, 2017.

37. Government of the Republic of Croatia. The Revised Implementation Plan for Water Utility Directives; Government of the Republic of Croatia: Zagreb, Croatia, 2010.

38. Bodik, I.; Sedlacek, S.; Kubaska, M.; Hutnan, M. Biogas Production in Municipal Wastewater Treatment Plants-Current Status in EU with a Focus on the Slovak Republic. Chem. Biochem. Eng. Q. 2011, 25, 335-340.

39. Ministry of Environmental Protection and Energy. Ordinance on Thermal Treatment of Waste (OG 75/2016); Official Gazzette: Zagreb, Croatia, 2016.

40. Zagreb Wastewater Ltd. 2010. Available online: http://www.zov-zagreb.hr/en/home/ (accessed on 21 August 2018).

41. Bachmann, N. Sustainable Biogas Production in Municipal Wastewater Treatment Plants; IEA Bioenergy: Massongex, Switzerland, 2015.

42. Vouk, D.; Nakić, D.; Štirmer, N.; Serdar, M. Possible disposal of sludge generated in the process of wastewater treatment in concrete industry. Hrvatske Vode 2015, 23, 277-286.

43. Rutz, D.; Mergner, R.; Janssen, R. Sustainable Heat Use of Biogas Plants: A Handbook; WIP Renewable Energies: Munich, Germany, 2015.

44. Fruergaard, T.; Christensen, T.H.; Astrup, T.F. Energy recovery from waste incineration: Assessing the importance of district heating networks. Waste Manag. 2010, 30, 1264-1272. [CrossRef]

45. Eriksson, O.; Finnveden, G. Energy Recovery from Waste Incineration-The Importance of Technology Data and System Boundaries on $\mathrm{CO}_{2}$ Emissions. Energies 2017, 10, 539. [CrossRef]

46. Komilis, D.; Kissas, K.; Symeonidis, A. Effect of organic matter and moisture on the calorific value of solid wastes: An update of the Tanner diagram. Waste Manag. 2014, 34, 249-255. [CrossRef] [PubMed]

47. Bennamoun, L. Solar drying of wastewater sludge: A review. Renew. Sustain. Energy Rev. 2012, 16, 1061-1073. [CrossRef]

48. FAO. Calculation Procedure for the Penman-Monteith Equation; FAO: Rome, Italy, 2018; Available online: http: //www.fao.org/docrep/X0490E/x0490e08.htm\#penman\%20monteith\%20equation (accessed on 1 May 2019).

49. Vouk, D.; Serdar, M.; Vučinić, A.A. Use of incinerated sewage sludge ash in cement mortars: Case study in Croatia. Tech. Gaz. 2017, 24, 43-51.

50. Nowak, B.; Pessl, A.; Aschenbrenner, P.; Szentannai, P.; Mattenberger, H.; Rechberger, H.; Hermann, L.; Winter, F. Heavy metal removal from municipal solid waste fly ash by chlorination and thermal treatment. J. Hazard. Mater. 2010, 179, 323-331. [CrossRef] [PubMed]

51. Chen, Y.-C.; Kuo, J. Potential of greenhouse gas emissions from sewage sludge management: A case study of Taiwan. J. Clean. Prod. 2016, 129, 196-201. [CrossRef]

52. Eggleston, S.; Buendia, L.; Miwa, K.; Ngara, T.; Tanabe, K. 2006 IPCC Guidelines for National Greenhouse Gas Inventories; Institute for Global Environmental Strategies (IGES): Hayama, Japan, 2006.

53. Government of the Republic of Croatia. Waste Management Plan of the Republic of Croatia for the Period 2017-2022; Government of the Republic of Croatia: Zagreb, Croatia, 2017.

54. Olofsson, M.; Sahlin, J.; Ekvall, T.; Sundberg, J. Driving forces for import of waste for energy recovery in Sweden. Waste Manag. 2005, 23, 3-12. [CrossRef] [PubMed] 
55. Dick, H.; Scholes, P. Comparing the Costs of Alternative Waste Treatment Options; WRAP: Banbury, UK, 2018.

56. LIFE Clim'Foot Project. The Bilan Carbone Clim'Foot Tool. 2016. Available online: http://www.climfootproject.eu/en/bilan-carbone\%C2\%AE-clim\%E2\%80\%99foot-tool (accessed on 15 March 2019).

(C) 2019 by the authors. Licensee MDPI, Basel, Switzerland. This article is an open access article distributed under the terms and conditions of the Creative Commons Attribution (CC BY) license (http://creativecommons.org/licenses/by/4.0/). 